\title{
Характеристика видового складу мікрофлори та її антибіотикорезистентність у дорослих пацієнтів кардіохірургічного профілю
}

\author{
Варбанець С. В., Фурман М. М., Марченко О. Ю., Філоненко Г. В.
}

\author{
ДУ «Науково-практичний медичний центр дитячої кардіології та кардіохірургії МОЗ України» (Київ)
}

\begin{abstract}
Важливою складовою профілактики інфекційних ускладнень (ІУ) у пацієнтів, котрі підлягають хірургічному втручанню на серці, є визначення носійства умовно патогенної мікрофлори (УПМ) починаючи з етапу госпіталізації та визначення факторів ризику та коморбідності. Мета роботи - визначити особливості видового складу мікрофлори слизових оболонок та їх антибіотикорезистентність у дорослих на етапі госпіталізації до кардіохірургічного стаціонару. Матеріали та методи. За період із квітня по червень 2018 р. бактеріологічно обстежено 109 пацієнтів, які перебували на стаціонарному лікуванні в ДУ «НПМЦДКК MO3 України» (м. Київ). Результати та обговорення. В результаті проведених бактеріологічних досліджень встановлено, що в більшості випадків зі зразків біологічних матеріалів респіраторного тракту обстежених пацієнтів висівали Staphylococcus aureus. Наступне місце за кількістю виявлення посіли Staphylococcus epidermidis - 57 (26,0\%), Staphylococcus haemolyticus - 15 (6,1\%). Серед каталазонегативних коків переважали Streptococcus spp. - 40 (18,3\%) та Enterococcus spp. - 5 (2,3\%). Також висівали грампозитивні палички Corynebacterium spp. - $2(0,9 \%)$ та Bacillus spp. - $3(1,4 \%)$ штами мікроорганізмів. Висновки. Проведений нами аналіз свідчить, що передопераційне виявлення мікрофлори пацієнта і визначення антибактеріальної чутливості могло б попередити розвиток інфекційних ускладнень та знизити рівень метицилін-резистентних форм мікроорганізмів.
\end{abstract}

Ключові слова: умовно патогенна мікрофлора, інфекційні ускладнення, антибіотикорезистентність.

Серцево-судинна хірургія за останні десятиліття суттєво еволюціонувала, однак хірургічні ранові ускладнення завжди були актуальними і дискутабельними темами $[1,2,8,10]$. Частота інфекційних ускладнень (IУ) після оперативних втручань на серці коливається в діапазоні від 2 до 14\%, що асоціюється з підвищеною захворюваністю та смертністю [5, 6, 9, 10]. Також слід зазначити, що інколи витрати на лікування ІУ можуть удвічі перевищувати лікування основного захворювання, а розвиток мікробіологічної резистентності стрімко зростає [1-3].

Важливою складовою попередження та профілактики ІУ у пацієнтів, котрі підлягають хірургічному втручанню на серці, є визначення носійства умовно патогенної мікрофлори (УПМ) починаючи з етапу госпіталізації та визначення факторів ризику та коморбідності $[1,4,6]$. Для ефективної антибіотикопрофілактики необхідно враховувати рівні природної резистентності та постійний ріст набутої резистентності УПМ, особливо родини Enterobacteriaceae, що продукують бета-лактомази розширеного спектру - БЛРС (ESBL - extended spectrum beta-lactamases) [1, 5, 6].

Мета роботи - визначити особливості видового складу мікрофлори слизових оболонок та їх антибіотикорезистентність у дорослих на етапі госпіталізації до кардіохірургічного стаціонару.
Матеріали та методи. За період із квітня по червень 2018 р. бактеріологічно обстежено 109 пацієнтів, які перебували на стаціонарному лікуванні в ДУ «НПМЦДКК МО3 України» (м. Київ).

Середній вік пацієнтів становив $62,8 \pm 10,5$ років

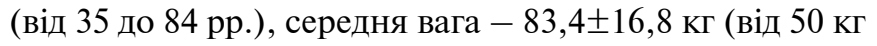
до 134 кг). Розподіл за статтю був таким: 75 (68,8\%) пацієнтів - чоловічої статі, 34 (31,2\%) - жіночої. Середня тривалість перебування у стаціонарі становила

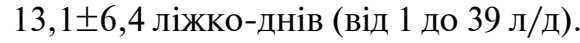

Розподіл пацієнтів згідно з класифікацією серцевої недостатності за Стражеском та Василенком був таким: CH I ст. - 41 (37,6\%) пацієнт, CH II А ст. - 63 (57,8\%) пацієнти, СН II Б ст. - 3 (2,8\%) пацієнти; за класифікацією Нью-Йоркської асоціації кардіологів NYHA I визначалась у 32 (29,4\%) пацієнтів, NYHA II у 46 (42,2\%), NYHA III - у 29 (26,6\%).

Дослідження біологічного матеріалу та інтерпретацію отриманих результатів проводили згідно з Наказом МО3 СРСР № 535 від 22.04.85 р. Ідентифікацію виділених мікроорганізмів проводили загальноприйнятими бактеріологічними методами, дотримуючись класифікації Бергі (1997). У деяких випадках для остаточної ідентифікації УПМ за видом використовували бактеріологічний аналізатор VITEC 2 COMPACT (bioMerieux). Аналіз даних чутливості проводили за 
клінічними рекомендаціями щодо визначення антибіотикочутливості, заснованими на рекомендаціях EUCAST-2017.

Статистична обробка даних проводилася за допомогою програм WHONET 5,6 та STATISTICA 6,0. Статистичну значимість різниць показників тестували за допомогою критерію Фішера. Відмінності вважали статистично значущими при р 0,05 .

Результати та обговорення. Із 109 досліджуваних пацієнтів $81(77,3 \%)$ підлягав хірургічному втручанню відповідно до об'єму ураження. У переважній більшості випадків $(\mathrm{n}=29,35,8 \%)$ було виконано ізольоване аортокоронарне шунтування. При ураженні клапанного апарату і коронарних артерій $(\mathrm{n}=10,12,4 \%)$ було виконано комбіноване хірургічне лікування.

Проаналізовані нами статистичні дані показують, що у $42(51,9 \%)$ пацієнтів були виконані хірургічні втручання при клапанній патології та ураженні висхідної аорти.

При аналізі супутньої патології виявлено, що 19 $(17,4 \%)$ пацієнтів мали підтверджений цукровий діабет II типу на момент госпіталізації, хоча підвищений рівень глюкози натще було зафіксовано у значно більшої кількості пацієнтів: рівень глюкози від 6 ммоль/л до 7 ммоль/л - у 40 (36,7\%) пацієнтів, від 7 ммоль/л до 10 ммоль/л - у 23 (21,1\%), 10 ммоль/л та вище - у 8 (7,3\%). Також у переважної більшості пацієнтів діагностували XXН різного ступеня, яка класифікована за швидкістю клубочкової фільтрації за формулою MDRD. У 49 (45\%) пацієнтів встановлено ХНH II ст., у $38(34,9 \%)-$ ХНH IIIA ст.; у $16(14,7 \%)-$ ХНH III Б ст., у $2(1,8 \%)-$ XHН IV ст., у $1(0,9 \%)-$ XHН V ст.

За досліджуваний період відібрано 218 зразків від 109 дорослих пацієнтів. Позитивний результат отримано в $129(59,1 \%)$ пробах. Нормальну мікрофлору верхніх дихальних шляхів зі зразків біологічних матеріалів респіраторного тракту виділено у 86 випадках від 51 пацієнта, що склало $39,5 \%$, тоді як у $3(1,4 \%)$ зразках росту мікрофлори отримати не вдалося. Мікробні асоціації з 2 культур виділяли у 61 (22,9\%) випадку, із $3-$ у 12 (5,5\%), асоціації з 4 та 5 культур - по одному $(0,5 \%)$ випадку відповідно.

За даними зарубіжних джерел, патологічним мікроорганізмом назофарингеальної ділянки у більшості випадків є Staphylococcus spp. [17], що корелює з даними у нашому дослідженні (Staphylococcus spp. - 59 \%). Згідно з даними зарубіжної літератури [16, 17], основними збудниками ранових ускладнень у післяопераційному періоді є грампозитивна флора. Аналіз даних вітчизняних досліджень мікробіологічного спектру збудників інфекційного ендокардиту свідчить про перевагу Staphylococcus spp. Так, у дослідженнях [15] основними збудниками інфекційного ендокардиту були Staphylococcus spp. (56\%) [17].
Проаналізовано, що із загальної кількості 219 досліджуваних штамів грампозитивні складали 178 ізолятів $(81,3 \%), 24$ (11,0\%) - грамнегативні мікроорганізми, загальна кількість грибкової мікрофлори - 17 $(7,8 \%)$ штамів.

В результаті проведених бактеріологічних досліджень встановлено, що в більшості випадків зі зразків біологічних матеріалів респіраторного тракту обстежених пацієнтів висівали Staphylococcus aureus. Наступне місце за кількістю виявлення посіли Staphylococcus epidermidis - 57 (26,0\%), Staphylococcus haemolyticus $15(6,1 \%)$. Серед каталазонегативних коків переважали Streptococcus spp. - 40 (18,3\%) та Enterococcus spp. 5 (2,3\%). Також висівали грампозитивні палички $\mathrm{Co}$ rynebacterium spp. $-2(0,9 \%)$ та Bacillus spp. $-3(1,4 \%)$ штами мікроорганізмів.

Також етіологічним агентом слизових оболонок дихальних шляхів дорослих пацієнтів виступила група грамнегативних бактерій, штами яких віднесено до групи Enterobacteriaceae - 21 (9,6\%) та неферментуючих мікроорганізмів - $3(1,4 \%)$ штами. Грибкових мікроорганізмів виділено 17 ізолятів, що становить 7,8\% (рис. 1).

Проаналізовано 55 клінічних штамів St.aureus, виділених від дорослих пацієнтів. За результатами аналізу даних виявлено суттєві відмінності резистентності досліджуваних штамів St.aureus до тестованих антибіотиків різних груп та класів. Зокрема, резистентність ізолятів St.aureus до природних пеніцилінів виявилася найбільшою, до якого нечутливими були 59,3\% (95\% CI $45,1-72,8)$ штамів. До цефокситину резистентними були 1,8\% (95\% CI 0,1-11,0) штамів St.aureus. Відповідно було виявлено $1,8 \%$ MRSA. Резистентність до фторхінолонів різних поколінь (ципрофлоксацин, левофлоксацин та офлоксацин) дещо різнилася: так,

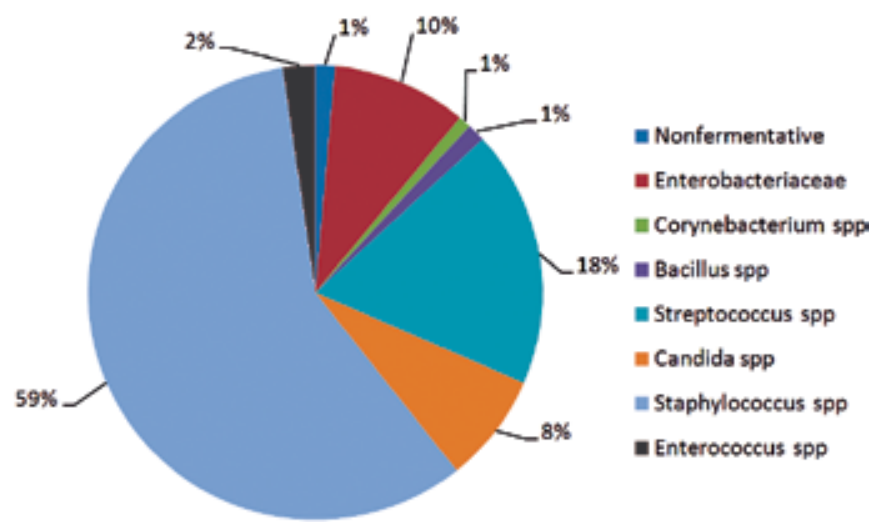

Рис. 1. Загальна кількість мікроорганізмів, виділених зі зразків біологічних матеріалів верхніх дихальних шляхів дорослих на етапі госпіталізації до кардіохірургічного стаціонару 


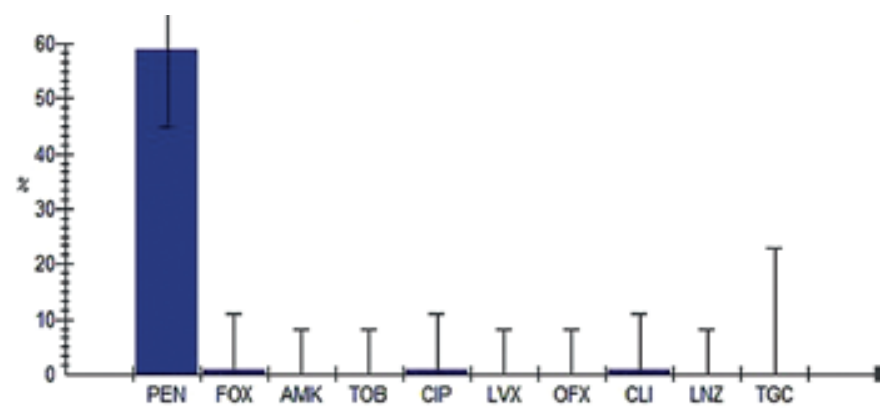

Рис. 2. Антибіотикорезистентність клінічних итамів Staphylococcus aureus ( $n=55)$

Примітка: PEN - бензилпеніцилін, FOX - цефокситин, АМК - амікацин, ТОВ - тобраміцин, СІР - ципрофлоксацин, LVX - левофлоксацин, OFX - офлоксацин, CLI - кліндаміцин, LNZ - лінезолід, TGC - тайгециклін

до ципрофлоксацину резистентність виділили у $1,8 \%$ (95\% CI 45,1-72,8), тоді як до левофлоксацину та офлоксацину резистентності не спостерігалося. Аміноглікозиди (амікацин і тобраміцин), а також тайгециклін і лінезолід відносно штамів St.aureus мали високу активність, зокрема, резистентність до цих антибіотиків не спостерігалася (рис. 2).

Резистентність клінічних штамів St.haemolyticus до пеніциліну була найбільшою - 80\% (95\%,CI 51,4-94,7). До цефокситину резистентність становила 66,7\% (95\%, CI 38,7-87,0). Відповідно MRSE становило 66,7\%. До решти тестованих антибіотиків резистентність коливалася в діапазоні від 13,3\% (95\%,CI 2,3-41,6) до 33,3\% (95\%,СI 13,0-61,3). Зокрема, резистентності досліджуваних штамів St.haemolyticus до лінезоліду та тайгецикліну не спостерігалося (рис. 3).

Із тестованих 10 антибіотиків найменшу активність відносно штамів Klebsiella pneuтопіае виявив цефуроксим (цефалоспорин II покоління), резистентність до якого була $81,8 \%$ (95\%, СI 47,7-96,8). До цефазоліну

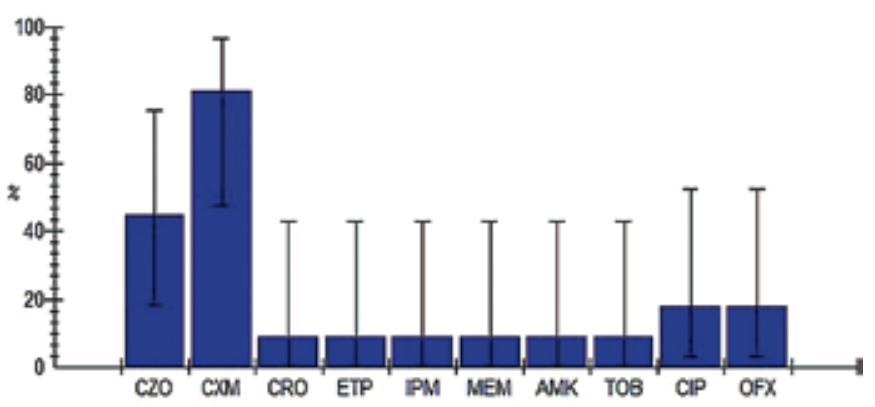

Рис. 4. Антибіотикорезистентність клінічних итамів Klebsiella pneumoniae ( $n=9)$

Примітка: CZO - цефазолін, СXМ - цефуроксим, CRO - цефтріаксон, ERT - ертапенем, IMP - іміпенем, MER - меропенем, AMK - амікацин, ТОВ - тобраміцин, СIP - ципрофлоксацин, OFX - офлоксацин

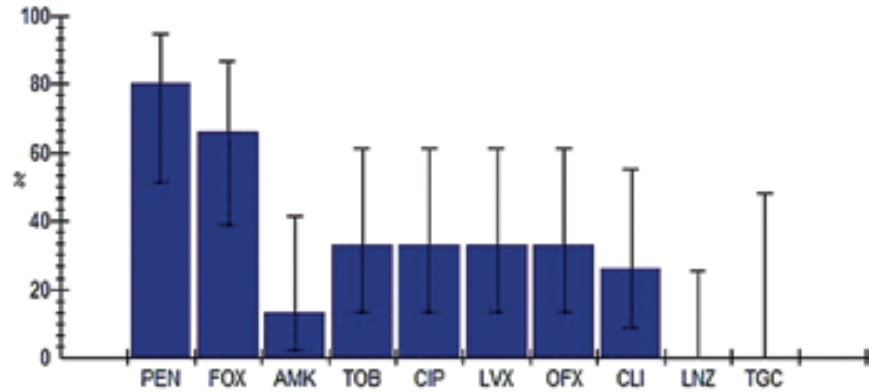

Рис. 3. Антибіотикорезистентність клінічних штамів Staphylococcus haemolyticus ( $n=15)$

Примітка: PEN - бензилпеніцилін, FOX - цефокситин, АМК - амікацин, ТОВ - тобраміцин, СІР - ципрофлоксацин, LVX - левофлоксацин, OFX - офлоксацин, CLI - кліндаміцин, LNZ - лінезолід, TGC - тайгециклін

(цефалоспорин I покоління) резистентність становила 45,5\% (95\%, CI 18,2-75,5). Зокрема, резистентність до цефалоспоринів III покоління, цефтріаксону склала 9,1\% (95\%, CI 0,5-42,9). До аміноглікозидів (амікацин, тобраміцин) та карбапенемів (іміпенем, меропенем та ертапенем) резистентність була виявлена у $9,1 \%$ (95\%, CI 0,5-42,9), як це видно на рис. 4.

Враховуючи досить високу частоту розвитку ІУ у дорослих після кардіохірургічних втручань, можливо зробити припущення, що вони пов'язані не тільки з екзогенною мікрофлорою пацієнта, а і з наявністю ендогенної або інших факторів, що збільшують ризик виникнення ІУ.

\section{Висновки}

1. Аналіз етіологічної структури показав, що до провідних патологічних збудників верхніх дихальних шляхів належать стафілококи, в першу чергу Staphylococcus aureus $(25,1 \%)$, найбільш активними до якого були левофлоксацин, офлоксацин, лінезолід, амікацин, тобраміцин і тайгециклін.

2. Проведений нами аналіз свідчить, що передопераційне виявлення мікрофлори пацієнта і визначення антибактеріальної чутливості могло б попередити розвиток інфекційних ускладнень і знизити рівень метицилін-резистентних форм мікроорганізмів $[6,10]$.

3. Згідно з аналізом супутньої патології виявлена гіперглікемія у $71(73,2 \%)$ пацієнта, і лише у 19 $(26,8 \%)$ із них встановлено діагноз цукрового діабету. Дана група пацієнтів (з раніше не діагностованою гіперглікемією) потребувала подальшого дообстеження, оскільки підвищений рівень цукру $\epsilon$ додатковим фактором ризику серцево-судинних захворювань та IУ [13, 14].

\section{Література}

1. Aref'eva LI, Gorskaya EM, Savost'yanova AO. Infekcionnye oslozhneniya bakterial'noj prirody v serdechno-sosudistoj hirurgii. Rossijskij medicinskij zhurnal. 2013; 3: 36-41. 
2. European Centre for Disease Prevention and Control. Rapid risk assessment: carbapenem-resistant Enterobacteriacae, first update. Stockholm: ECDC; 2018. Available from: https://ecdc.europa.eu/sites/portal/files/ documents/RRA-Enterobacteriaceae-CarbapenemsEuropeanUnion-countries.pdf

3. Filonenko GV, Talalaev OS, Kyryk DL, Kovalenko NN, Skorohod IN, Salamanina AA.Single center study of ESBL-related strains of Enterobacteriaceae collected from clinical specimens of infants with congenital heart disease using multiplex PCR amplification. Biopolym. Cell. 2017; 33(2):92-101.

4. Filonenko HV, Salamanina AO, Kyryk DL. Monitorynh mikrobiolohichnoho peizazhu $\mathrm{u}$ ditei $\mathrm{z}$ vrodzhenymy vadamy sertsia. Visnyk sertsevo-sudynnoi khirurhii. 2016; 1(24):86-88.

5. Sobkova ZhV, Filonenko HV, Surmasheva OV, Rosada MO. Vyvchennia vydovoho skladu mikroorhanizmiv v bioplivkakh na sudynnykh ta sechovykh kateterakh u bahatoprofilnomu statsionari. Scientific Journal «Science Rise: Biological Science». 2017; 2 (5): 38-42.

6. Cluzet VC, Gerber JS, Nachamkin I, Metlay JP, Zaoutis TE, Davis MF et al. Duration of colonization and determinants of earlier clearance of colonization with methicillin - resistant Staphylococcus aureus. Scientific Journal "Clin Infect Dis". 2015; 60:1489-1496.

7. Anderson DJ, Podgorny K, Berrhos-Torres SI. Strategies to prevent surgical site infections in acute care hospitals. 2014; 35:605.

8. Bratzler DW, Dellinger EP, Olsen KM. Clinical practice guidelines for antimicrobial prophylaxis in surgery. Am $\mathbf{J}$ Health Syst Pharm. 2013; 70:195.

9. Rodriguez-Bano J, Gutierrez-Gutierrez B, Machuca I, Pascual A. Treatment of Infections Caused by Extended-
Spectrum-Beta-Lactamase-, AmpC-, and CarbapenemaseProducing Enterobacteriaceae. ClinMicrobiol Rev. 2018; 14(2): 31

10. Sievert DM, Ricks P, Edwards JR, Schneider A, Patel J, Srinivasan A, et al. Antimicrobial-resistant pathogens associated with health care - associated infections. Summary of data reported to the National Healthcare Safety Network at the Centers for Disease Control and Prevention. Infect Control HospEpidemiol. 2013; 34 (1):1-14.

11. Stbrenburg E, Mack D. Extended - spectrum Я-lactamases: Implications for the clinical microbiology laboratory, therapy and infection control. J Infect. 2003; 47(4): 73-95.

12. Cowie CC, Rust KF, Ford ES, et al. Full accounting of diabetes and pre-diabetes in the U.S. population in 19881994 and 2005-2006. DiabetesCare. 2009; 32:287.

13. David K McCulloch, Rodney AHayward. A Screening for type 2 diabetes mellitus. UpTodade. 2017.

14. Park C, Guallar E, Linton JA, Lee DC, Jang Y, Son DK,et al. Fasting glucose level and the risk of incident atherosclerotic cardiovascular diseases. Diabetes Care. 2013; 36: 7-11.

15. Krykunov OA, Buriak RV, Koltunova HB, Spysarenko SP, Pustovalova HO, Khmelevskyi AM. Analiz antybiotykorezystentnosti zbudnykiv aktyvnoho klapannoho infektsiinoho endokardytu. Visnyk sertsevosudynnoi khirurhii. 2017; 3 (29):48-52.

16. Thomas L Holland, Larry MBaddour, Arnold S Bayer, Bruno Hoen, Jose MMiro and Vance G.Infective endocarditis. Scientific Journal"Primer". 2016; 4:2-4.

17. Lemaignen A, Birgand G, Ghoodhbane W, Alkhoder A, Lolom I, Belorgey S. Sternal wound infection after cardiac surgery: incidence and risk factors according to clinical presentation. Scientific Journal "Clinical Microbiology and Infection". 2015; 7: 2-3.

\title{
The characteristics of the microflora species composition and its antibiotic resistance in adult patients at cardiac surgery department
}

\author{
Varbanets S. V., Furman M. M., Marchenko O. Y., Filonenko G. V. \\ GI “The Scientific-Practical Children's Cardiac Center The Ministry Of Health Care Of Ukraine” (Kyiv)
}

The most important component of the prevention of infectious complications (IC) in patients undergoing cardiac surgery is the determination of the carrier state of opportunistic pathogenic microflora (OPM) from the admission and the identification of risk factors and comorbidity. For effective antibiotic prophylaxis, it is necessary to take into account the levels of natural resistance and the continuous growth of the acquired resistance of the OPM, especially the Enterobacter spp., producing ESBL (extended spectrum beta-lactamases). Purpose of the study - determine the features of the species composition of the microflora of the mucous membranes and their antibiotic resistance in adults at the admission to the cardiac surgery department. Material and methods. 109 patients treated in GI "CPCCC MHC in Ukraine" during the period from April to June 2018 were performed blood cultures. Results and discussion. The results of performed bacteriological studies showed that in most cases in samples of biological materials of the respiratory tract were identified Staphylococcus aureus. The second place were taken by Staphylococcus epidermidis - 57 (26.0\%), Staphylococcus haemolyticus - 15 (6.1\%). Among catalase-negative cocci, the most common were Streptococcus spp. - 40 (18.3\%) and Enterococcus spp. - 5 (2.3\%). Also the next strains of microorganisms were cultured: the gram-positive rods Corynebacterium spp. $-2(0.9 \%)$ and Bacillus spp. $-3(1.4 \%)$. From the 10 tested antibiotics, cefuroxime (II generation cephalosporin) demonstrated the lowest activity against Klebsiella pneumoniae strains with resistance of $81.8 \%$ (95\%, CI 47.7-96.8). Conclusions. Our analysis shows that the preoperative detection of the patient's microflora and the determination of antibacterial sensitivity could prevent the development of infectious complications and reduce the level of methicillin-resistant forms of microorganisms. The analysis of the etiological structure showed that staphylococci are the most common pathological agents in the upper respiratory tract.

Key words: opportunistic pathogenic microflora, infectious complications, antibiotic resistance. 